\title{
TAPANI OJASTI
}

\section{OIKEUDESTA OLLA IHMINEN}

Muistan perulaisen ammattiyhdistyslakimiehen, joka oli myös perustuslain professori San Marcosin yliopistossa, Limassa. Muistan tapaamisemme Costa Rican yliopiston campuksella: me molemmat pelkäsimme, hän maastakarkoitusta, minä ensimmäistä ihmisoikeustapaustani. Ystävääni oli vankilassa tartutettu tahallisesti hepatitis, ei vain häneen, vaan myös tuhansiin muihin. Kuolemansyyksi tulisi siten sairaus eikä ampumahaava. Muistan hyvin tuon pelokkaan ja sairaan miehen, Mexico otti hänet vastaan ja siellä hän toipui ja sai hoitoa.

Muistan kaksi pientä Mapuche-intiaanityttöä Temucosta, Chilen eteläosasta. Kattopellillä peitetyn puukehikon keskellä oli maalattialla nuotio, jota he paksujen villahameittensa keskeltä tuijottivat. Vanhemmat keskustelivat siitä, miten valkoiset siirtolaiset viljelivät nyt laaksoja ja he tilkkuja vuoristossa. Alkuperäisväestöstä oli tullut vähemmistö ilman oikeuksia.

Muistan Thaimaan passipoliisin ulkomaalaisten pidätyssellit, jossa Burman sotilasdiktatuuria paenneet "laittomat maahanmuuttajat" elivät kuin sillit tynnyrissä. Kivuliaat ja toivottoman toivoa heijastavat kasvot painautuivat joka kalterituumaa vastaan.

Muistan paljon muutakin. Kaikki nuo muistot olivat läsnä ja jotenkin lähtöviivalla, kun Yhdistyneiden Kansakuntien ihmisoikeuksia käsittelevä maailmankongressi alkoi Wienissä kesäkuun kymmenentenä. Sisimmässä eli kai toivo, että ne ihmisten ja ihmisryhmien alistamiset, joita oli nähnyt ja jotka jotenkin vaivasivat, vaivaisivat muitakin.

\section{Kolmen kerroksen väkeä}

Suuret kongressit ovat valintatalomaisia. Ruokalista on laaja, toiminta ja tiedotustapahtumia jatkuvasti.
Yläkerran kokous oli "virallinen". Virkoja tuntuivat omaavan 40-60 vuotiaat miehet, joiden puvut olivat räätälityötä ja joiden kasvoilta voi lukea reaalipoliitikon itsevarmuuden tuottaman kohteliaan hallintovirkamiehen sisäistetyn roolin. Kukaan ei liikkunut kömpelösti. He tiesivät, että heidän kerroksessaan yleiskokouksessa pidettiin yleisluonteisia puheenvuoroja, maakohtaiset asiat oli jo alusta alkaen päätetty jättää sivuun. Siellä hallitus hallituksen jälkeen vakuutti tukevansa ihmisoikeuksia.

Yläkerrassa kokoontui myös loppuasiakirjaa valmisteleva toimikunta. Tuon toimikunnan lopputuloksen tuli heijastaa valtioiden ja liittoutumien näkemyksiä ihmisoikeusasioiden tulevaisuudesta. Keskeisiksi asioiksi nousivat ihmisoikeuksien universaalisuus (samat maailmanlaajuiset yhteiset ja yleiset periaatteet) ja mahdollisuus suositella YK:lle laajat valtuudet omaavan ihmisoikeuskomisaarin nimittämistä.

Yläkertaa ja loppuasiakirjaa hallitsi Kiina. Se esti universaalisuuden periaatteen läpimenon, etnisyys, kulttuuri ja valtio määrittelevät yleisten periaatteiden sijasta. Myöskään YK:n valtaa itsenäisen ihmisoikeusvirkamiehen muodossa se ei tukenut; valtioilla tuntui olevan oikeus suvereenisuuteen, heidän sisäisin asioihinsa ei saa puuttua. Dalai Lama ei, Kiinan painostuksesta, saanut osallistua kongressiin ja laman kourissa kamppailevat länsimaat varoivat astumasta nykyisen ja tulevan kauppakumppaninsa, Kiinan, varpaille. Olihan kaikille selvää sekin, että turvallisuusneuvostopaikan omaava maailmanmahti on saavuttanut paljon alueellista ja taloudellista vaikutusvaltaa.

Alakerta, kansalaisjärjestökerros, oli toisenlainen. Kun yläkerta pidättäytyi kaikesta maakohtaisesta, tapauskohtaisesta, henkilökohtaisesta ja oikeustajukysymyksistä, niin alakerrassa näitä oli tarjolla sitäkin enemmän. Kaikki näyttelyn, esitteitä ja painotuotteita tuoneet olivat vakuut- 
tuneita oman asiansa tärkeydestä. Vahinko, että kansalaisjärjestöiltä puuttui yleisö: valtaosa ajasta tuntui menevän toinen toisensa käännyttämiseen, yläkerran väki ja ulkopuoliset vierailivat vain harvoin. Paljon merkittäviä yhteisiä kokouksia, asioita ja kontakteja tapahtui kuitenkin kansalaisjärjestöjen kesken.

Kolmantena "kerroksena" TV, radio, toimittajat ja median muut edustajat välittivät virallisen kokouksen ja kansalaisjärjestöjen tietoja eri puolille maailmaa. Kahden viikon ajan ihmisoikeuksista uutisoitiin.

\section{Ihmisoikeudet aikuiskasvatuksessa}

Onko aikuiskasvatuksessa, ja kasvatuksessa yleensä, olemassa sellainen arvopohja, jonka varaan voi rakentaa, vai onko arvotyhjiössä tapahtuvasta "know-how" ajattelusta tullut yhteiskunnassa vallitseva hyväksytty suuntaus? Tätä jäin ajattelemaan, kun palasin tuosta YK:n kokouksesta. Onko se hellimämme ajatus länsimaisesta "humanismista" vain yksi myytti muiden seassa? Eikö maailmaamme, yhteiskuntaamme ja itse kutakin ohjaa kasvavassa määrin talousmaailman sanelu?

Jos ja kun kuljemme tai kulkeudumme kohti kansainvälisempää maailmaa, jossa suvaitsevaisuus, ymmärrys ja yhteisen arvopohjan etsintä on joka päivä ajankohtaisempaa, voisi aikuiskasvatus löytää ihmisoikeusajattelussa lähtökohdan sellaisen arvopohjan kehittämiselle, joka mahdollistaisi erilaisuuden kohtaamisen tuhoamatta kohtaajia.

Perulainen asianajaja, intiaanitytöt, laittomat maahanmuuttajat, kurdit ja palestiinalaiset odottavat vielä sitä ymmärrystä ihmisestä ja yhteiskunnasta, jossa laki kohtaa oikeuden, pohjoinen kohtaa etelän, omatunto kohtaa todellisuuden ja talous todelliset tarpeemme.

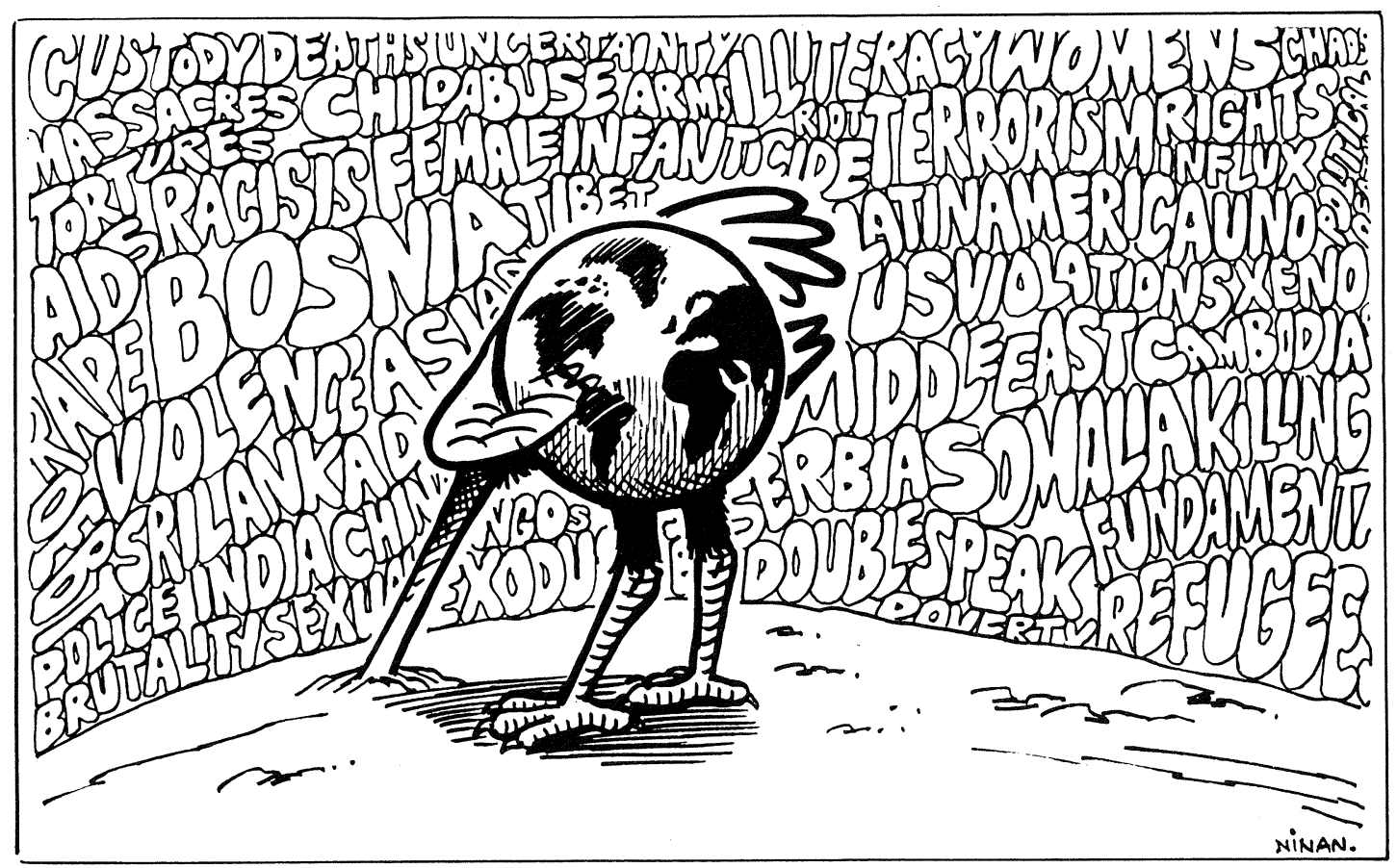

"Custody...deaths...massacres...uncertainty...child abuse...arms...illiteracy... women's rights...female infanticide....rape...chaos...terrorism...influx...Latin America...violations...Serbia...Somalia...killing...fundamentalism...police...Sri

Lanka...Bosnia...aids...tortures...Asia...Tibet...India...China...brutality...doublespeak... poverty...refugees...Middle East...Cambodia...executes..." Muutamia avainsanoja Maailman ihmisoikeuskonferenssin lehden Terravitan piirroksesta. 